\title{
Analytical Study on the effectiveness of strategies adopted for Employee Retention in the Organized Apparel Retail Sector
}

\author{
Mrs. Trupti Sachin Gupte \\ Assistant Professor - HR, PTVA's Institute of Management \\ Dr. Swati Sabale \\ Director, Hashmatrai and Gangaram Himathmal Mansukhani Institute of Management
}

\begin{abstract}
Many believe employee retention as connecting to the efforts by which employer's put efforts to retain the employees in their workforce. Employee Retention turns out to be tactic rather than result. It is essential to initially pinpoint the main driver of the maintenance issue before actualizing a program to address it. When distinguished, a program can be custom fitted to meet the special needs of the association. It is significant for representatives to comprehend their vocation way inside an association to spur them to stay in the association to accomplish their own vocation objectives. Through reviews, conversation and study hall guidance, representatives can all the more likely comprehend their objectives for self-improvement. Executive instructing can be utilized to construct skills in pioneers inside an association. Training can be valuable in the midst of hierarchical change, to build a pioneer's adequacy or to urge directors to execute instructing systems with peers and direct reports.
\end{abstract}

Key Words: - employee retention, overview of apparel retail sector, new normal and perspectives of apparel retail sector.

\section{Introduction}

Many organizations think their employees are their asset. Companies not only provide great conditions but ensure that their employees are highly engaged. Therefore company needs to realize the importance of employee retention as a part of successful business.

Retention means employer or company wishes that their employees don't quite their jobs.

Success of any business mostly depends on retention of skilled employees. Employee turnover may result into loosing knowledge and skills and may affect organization's effectiveness. If a company loses an employee then it not only effect on loosing productivity but also increase a cost of recruiting, selecting and training to a new employee.

Every company always invest their time and money to motivate new joiner, also make them ready for any challenge and put them with employees in the organization. It is bad for company if their fully trained employees leave the organization thus retain such employees is more important.

Retention of employees is an ability which keeps employees in an organization. Whereas employee turnover is employee leaves the company. But most of the time company's main motive is to stay back the employees in the organization. Efforts are taken to retain those 
employees who are valuable and contributing employees. To retain employees of company employer uses various techniques, programs, tools and resources for longer period of time. Programs such as career development in that organization enhance people and help them to get employees' personal objectives with company's goals.

\section{Overview of Retail Sector:}

Due to Entry of Various New Competitors in The Market the Indian Merchandise Companies Has Appeared as One of The Most Vigorous and Accelerating Companies. In 2017, Entire Utilization Expenditure Was Anticipated to Extend Approximately United States Dollars 3,600 Hundred Crores from United States Dollars 1,824 Hundred Crores. Over 10 \% Of India's GDP That Is Gross Domestic Product and All Over $8 \%$ Of the Application Was in Statement. Fifth Greatest International Destination in The Retail Trade Extent Was India On the Globe.

After Countries Like United States, Germany, Canada, China, U.K, Japan, Australia, France, Italy And Switzerland, India Is On $16^{\text {th }}$ Rank According to Foreign Direct Investment Confidence Index.

\section{Literature Review}

\section{Literature Review on employee retention in Maldives retail sector Information:}

This research is done by Mariyam Imna (School of Accounting and Business Management FTMS College, Malaysia) and Zubair Hassan (School of Accounting and Business Management FTMS College, Malaysia) Vol 3 (no.1) April 2015 ISSN: 2289-4519 copyright 2015. The study is mainly based on influence of employee retention by human resource development department. The research was done on the basis of questionnaire and on that base survey was taken in around 14 retailers in Maldives.

In every organization the human resource department work as the main pillar. If the HRM department of a company is not proper then that company may face many problems in its growth. This research was mainly based on what strategies were used by the HRM for employee retention. Many researches has been done regarding the employee retention in different sectors such as IT, banking, retail etc. the most of the GDP of Maldives by retail sector was around $13 \%$ and it is considered as the main pillar of the economy in Maldives.

\section{Conclusion:}

1. It is observed that the career development shows positive influence in the organization. Though it generally does not happen on regular basis in the organization from where the samples were collected. But still it plays an important role in employee retention.

2. It is observed that employee does not seek any value in training and development. Though it increase the productivity level and gain in their knowledge. If the career development and training and development are linked together then it can have positive influence in the organization.

3. Similarly performance appraisal alone itself does not show positive impact. But if it is linked with rewards and compensation then it show positive influence in the organization. Because the employee consider it as one and the same. 


\section{Employee turnover and organizational performance: a study of the Brazilian retail sector}

\section{INFORMATION:}

This research is done by Luciana Carvalho de Mesquita Ferreira and Ciro Barbosa de Aquino Almeida vol 12. No 4 ISSN 1808-2386. The Brazilian organizations were facing various problems in retaining employees. But since past two decades it has marked as stabilized growth of the economy and the number of jobs. Though there are various organizations in Brazil but the retail sector is one of the best organizations for its growth and employee retention. This study was to investigate the relationship between employee turnover and performance in retail sector. To achieve this target the researcher has done some survey in a single company in its various branches and also some test were done about whether the stores with lower employee has better financial and sales turnover supported with the past studies. Their primary objective was to test some personnel management specially training and recognition effect on employee turnover rate.

\section{CONCLUSION:}

The research was about to investigate the relationship between the employee turnover and organizational results. Their motivation emerged from conciliation of the theoretical perspective, which mainly indicates that high worker turnover tends to impair companies' results, with the situational context, which shows a trend for shorter job duration, mainly in the retail sector, despite the country's strong economic growth over the past decade. With respect to the limitation of the study the author only studied about a single company of retail sector in construction material. So the results cannot be generalised to other firm sectors.

\section{Flexible working as an employee retention strategy in developing countries}

\section{INTRODUCTION}

This research is done by Idris Aida ISSN: $0974-455 \mathrm{X}$ Vol 14 No.2 and the topic is flexible working as an Employee Retention Strategy in Developing Countries. The changes in factors such as demographic, cultural, economic and legal environment had an impact on many aspects of Human Resource Management including employee recruitment and retention strategies. The factors which were considered in Human Resource Management for employee recruitment and retention strategies includes monetary factors and Non-monetary benefits, monetary benefits includes salary, bonus and allowances and Non-monetary benefits includes flexible working which might be used to manage employee turnover. The researcher had adopted a fresh approach to the subject by learning the effects of five different types of flexible practice i.e. flex time, job sharing, flex leave, flex career and flex place on employee retention in Malaysia. Additionally instead of observing a cross section of local forms the research is based on competitive nature in banking sector where more importance is given to talent. Malaysia banking sector suffered an increase in employee turnover from $11 \%$ in 2010 to $15 \%$ in 2011. The above paper discuss the large case study of flexible working and employee retention in Malaysia banks. 


\section{CONCLUSION}

The researcher had carried out the above study to find out potential effects on five types of flexible working practices on employee retention in Malaysian banks. The findings above helped to understand the possible antecedents and outcomes of flexible practices from the research. The importance of research lies in three areas:-

- Examining from managerial perspective the various effects of five different types of flexible practices on employee retention.

- It had helped to generate a better framework of flexible working and also employee retention by considering environmental and organisational factors.

- It had helped to understand different trends in banking sector.

So from the above research it can be concluded that flexible practices can improve employee retention in Malaysian banks with the help of other factors.

\section{Research Methodology}

4.1 Objectives of the Study:

The study is designed to analyze the factors influencing employee retention among the Organized Apparel Retail sector in Mumbai, with the following objectives.

1. To explore the various factors which influences employee retention.

2. To study the current Training and Development activities and identify whether it results in enhanced coordination among employees at their workplace, leading to retention.

3. To study and analyse the impact of flexi work policies to enhance the overall workforce satisfaction in the organisation.

4. To Study and analyse whether Cross functional job rotation leads to employee Retention.

5. To Study and analyse the impact of higher education in retaining the employees.

\subsection{Hypothesis of the study}

$\mathrm{H} 1_{\mathrm{A}}$ Various factors does have significant impact on employee retention.

$\mathrm{H} 1_{0}$ Various factors does not have significant impact on employee retention.

$\mathrm{H} 2 \mathrm{~A}$ Training and Development has significant impact on mutual coordination between employees leading to higher retention.

$\mathrm{H} 20$ Training and Development does not have significant impact on mutual coordination between employees leading to higher retention.

$\mathrm{H} 3{ }_{\mathrm{A}}$ Flexi work policies enhances the overall workforce satisfaction in the organization and has a positive relationship for retaining employees.

$\mathrm{H} 3{ }_{0}$ Flexi work policies does not enhance the overall workforce satisfaction in the organization and does not have a positive relationship for retaining employees.

$\mathrm{H} 4_{\mathrm{A}}$ Cross functional Job rotation reduces the work monotony and has a positive relationship for retaining employees.

$\mathrm{H} 4{ }_{0}$ Cross functional Job rotation does not reduce the work monotony and does not have a positive relationship for retaining employees.

$\mathrm{H} 5_{\mathrm{A}}$ Organisations encouraging for Higher Education to their employees has significant impact on retention. 
$\mathrm{H} 5_{0}$ Organisations who do not encourage for Higher Education to their employees does not have a significant impact on retention.

\subsection{Description of Population}

The research population consists of 52 employees working in apparel retail sector. The employees consists of people working in various functions in apparel retail sector with an experience of minimum three years and having maximum educational qualification as graduation and minimum educational qualification as $12^{\text {th }}$ std.

Description of Population is given in Table 1 below

\begin{tabular}{|l|l|l|l|}
\hline Work Experience & $\begin{array}{l}\text { Maximum } \\
\text { Qualification }\end{array}$ & $\begin{array}{l}\text { Minimum } \\
\text { Qualification }\end{array}$ & $\begin{array}{l}\text { Total number of } \\
\text { employees }\end{array}$ \\
\hline 3 to 5 years & Graduation & $12^{\text {th }}$ std & 52 \\
\hline
\end{tabular}

\subsection{Sampling Technique - Convenience}

Convenience sampling technique, a sub method of Non Probability sampling is used. This sampling technique does not afford any basis for estimating the probability that each item in the population has of being included in the sample.

In this type of sampling, items for the sample are selected deliberately by the researcher.

4.5 Data collection methods and instruments

\subsubsection{Demographic Details of the population.}

Personal information sheet is designed to get demographic details of the population such as age, gender, educational qualification, work experience, income, family details, and marital status. 4.5.2 Questionnaire

To assess employee retention a comprehensive questionnaire is designed by the researcher.

\subsubsection{Online Questionnaire}

Structured and Pre-Planned online questionnaire was shared by using Google docs platform during lockdown time on the selected set of the population in a certain location.

\section{Data Analysis and Interpretation}

1. No. of years of work in the organisation

\begin{tabular}{|l|l|}
\hline No. of Years & Responses \\
\hline 3-5 Years & 27 \\
\hline 6-10 Years & 11 \\
\hline 11-15 Years & 9 \\
\hline More than 15 Years & 5 \\
\hline
\end{tabular}




\section{Work Experience}

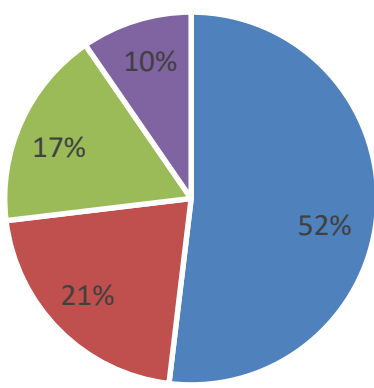

- 3-5 Years - 6-10 Years - 11-15 Years - More than 15 Years

The above data and graph provides the detail of how many years the employees are working in the organization. $52 \%$ of the employees are having work experience of 3-5 years, $21 \%$ of the employees are having work experience of 6-10 years, $17 \%$ of the employees are having work experience of 11-15 and 10\% of the employees are having work experience of more than 15 years.

2. Training and Development activities carried out by the organisation

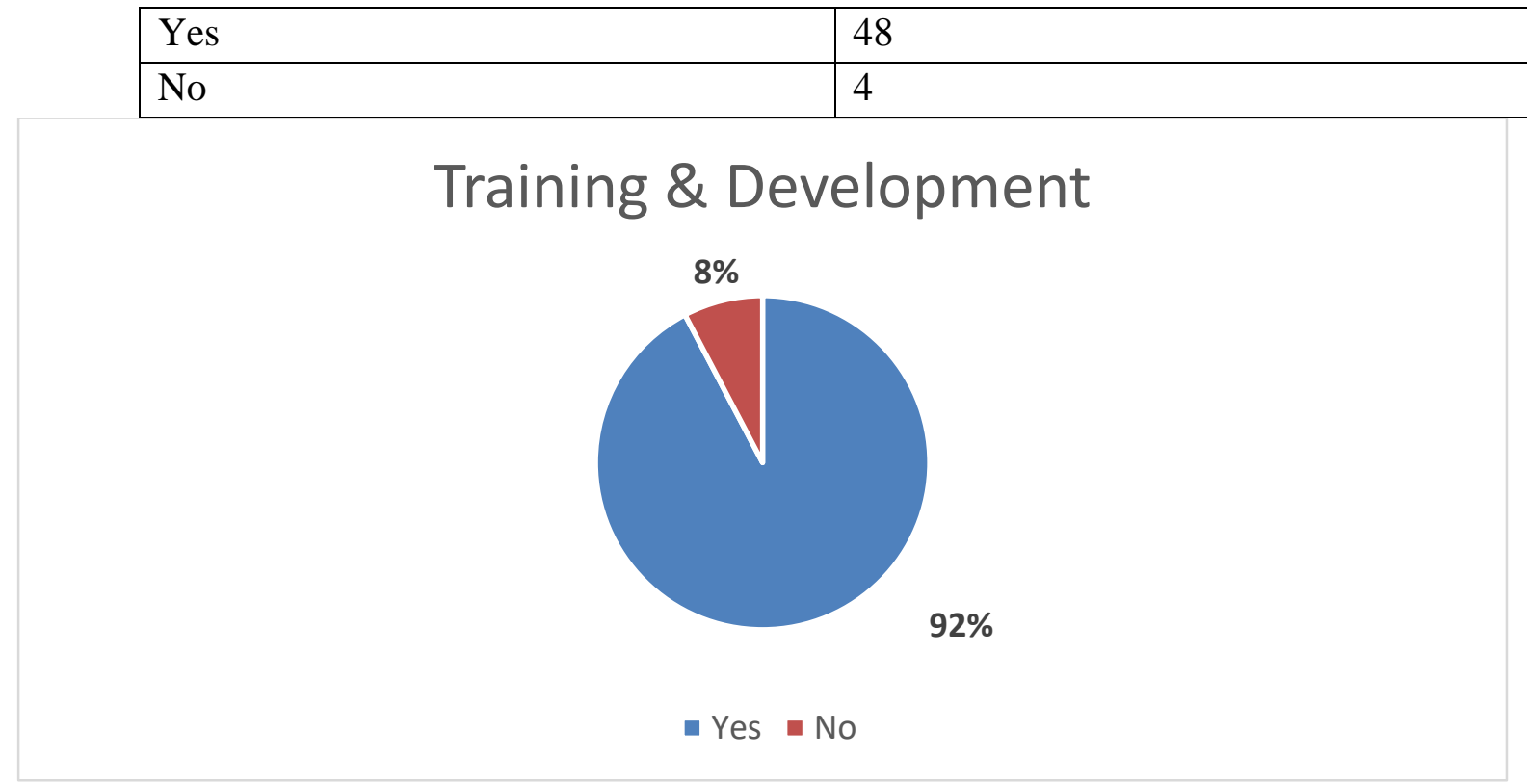

The above data and graph provides the details regarding the training and development activities carried out by the organisation. After analysing the above data and graph it is found that $92 \%$ of the organization are providing training and development activities and $8 \%$ of the organization does not provide any training and development activities. 
3. Current Training and Development activities adopted by the organisations

\begin{tabular}{|l|l|}
\hline Management Development & 32 \\
\hline Soft skills Development & 31 \\
\hline $\begin{array}{l}\text { Technical Skills Development } \\
\text { (Department wise training) }\end{array}$ & 25 \\
\hline Personal Effectiveness & 26 \\
\hline Basic Skill Development & 29 \\
\hline Time Management & 23 \\
\hline Effective Leadership & 25 \\
\hline
\end{tabular}

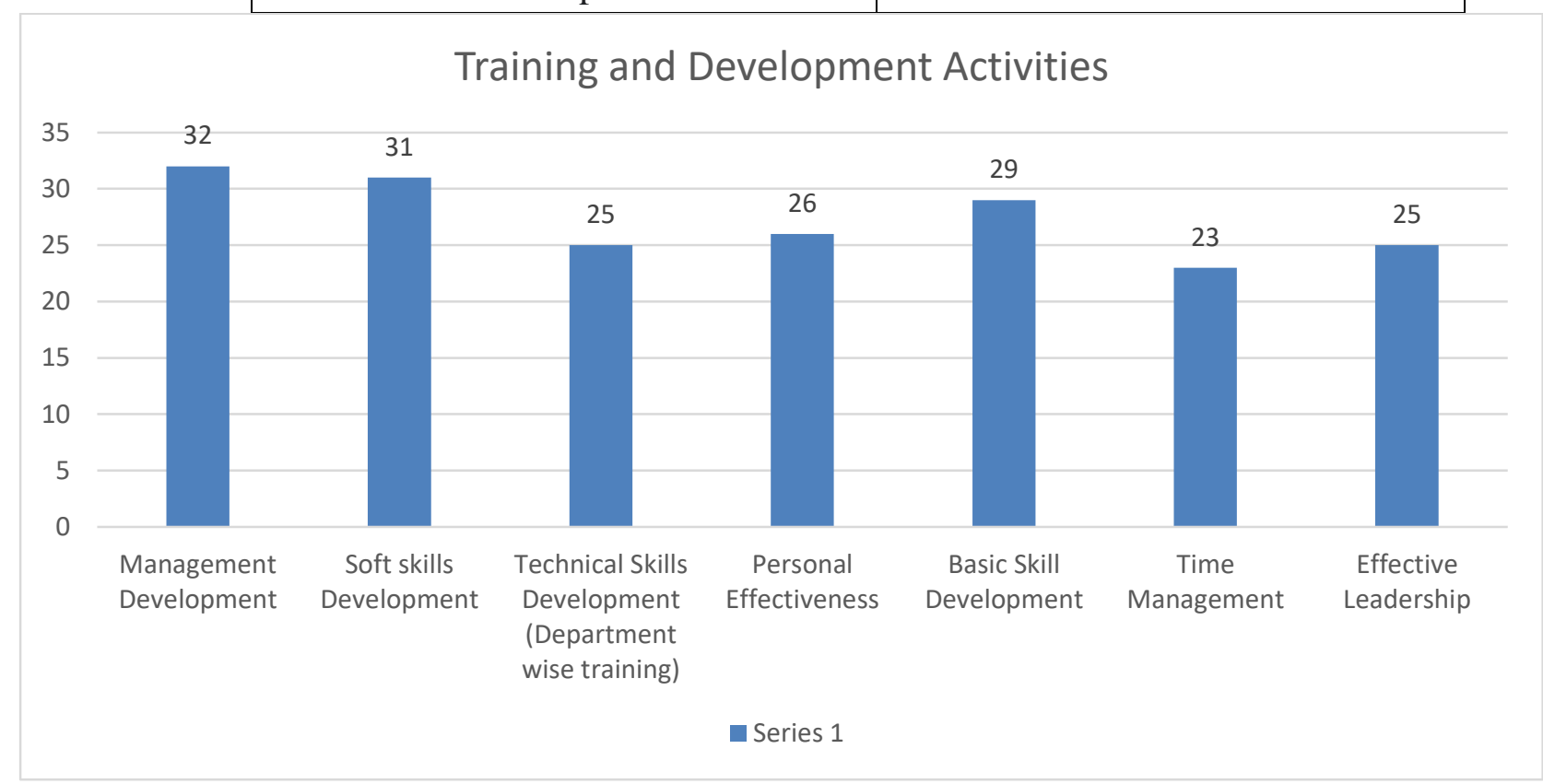

The above data and graph provides the detail of current training and development activities provided by the organisations. 32 respondents mentioned that there organisation provides them with management development training, 31 respondents mentioned that there organisation provides them with soft skill development training, 25 respondents mentioned that there organisation provides them with technical skill training, 26 respondents mentioned that there organisation provides them with training for their personal effectiveness, 29 respondents mentioned that there organisation provides them with basic skills training, 23 respondents mentioned that there organisation provides them with time management training and 25 respondents mentioned that there organisation provides them with training, required for effective leadership.

4. Types of On the Job Training Program

\begin{tabular}{|l|l|}
\hline Coaching & 32 \\
\hline Mentoring & 29 \\
\hline Job Rotation & 21 \\
\hline
\end{tabular}




\section{On the Job Tranings}

26

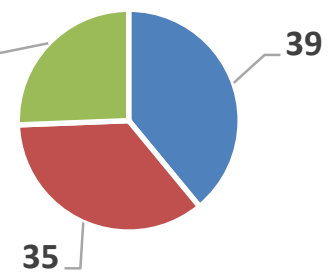

- Coaching - Mentoring - Job Rotation

As shown in the above data and graph the organizations are providing on the job training in different forms such as Coaching, Mentoring and Job Rotation.

5. Type of Off the Job Training Program

\begin{tabular}{|l|l|}
\hline Lectures And Conferences & 36 \\
\hline Simulation Exercises & 22 \\
\hline Sensitivity Training & 18 \\
\hline
\end{tabular}

Off the Job Trainings

$24 \%$

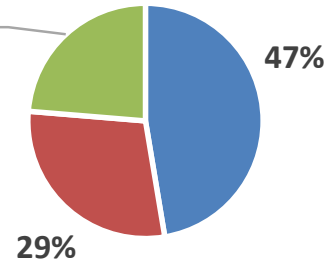

- Lectures And Conferences

- Simulation Exercises

- Sensitivity Training

As shown in the above data and graph the organizations are providing off the job training in different forms such as Lectures and Conferences, Simulation exercises and Sensitivity training.

6. Training activities leads to Career Growth Opportunities

\begin{tabular}{|l|l|}
\hline Strongly Agree & 23 \\
\hline Partially Agree & 3 \\
\hline Agree & 22 \\
\hline Neutral & 3 \\
\hline Disagree & 0 \\
\hline Partially Disagree & 0 \\
\hline Strongly Disagree & 1 \\
\hline
\end{tabular}




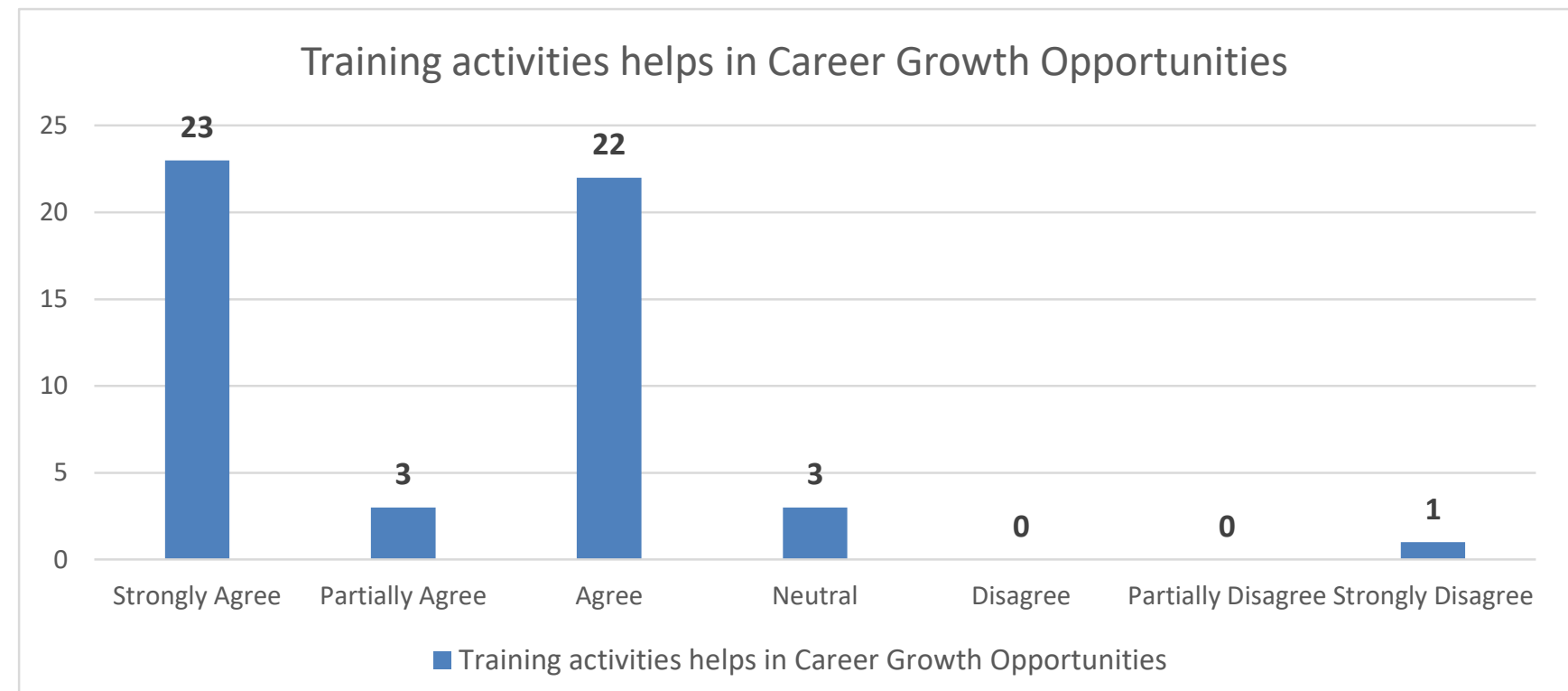

23 respondents strongly agreed that training activities helps in career growth opportunity, 3 respondents partially agreed that training activities helps in career growth opportunity, 22 respondents agreed that training activities helps in career growth opportunity, 3 respondents were neutral and 1 respondent strongly disagreed that training activities helps in career growth opportunity.

7. Training Program results in better work efficiency

\begin{tabular}{|l|l|}
\hline Yes & 47 \\
\hline No & 5 \\
\hline
\end{tabular}

Training Program results in better work efficiency

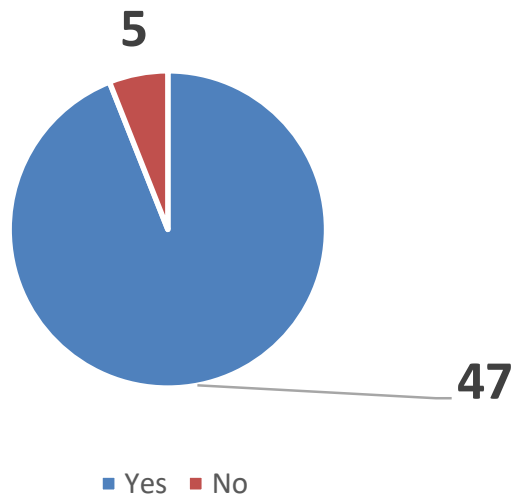

It shows that 47 respondents agreed that training program results in better work efficiency and 5 respondents did not agree to the statement.

8. Training activities have resulted in better co-ordination among work groups

\begin{tabular}{|l|l|}
\hline Yes & 50 \\
\hline No & 2 \\
\hline
\end{tabular}


Training activities results in better co-ordination among work groups

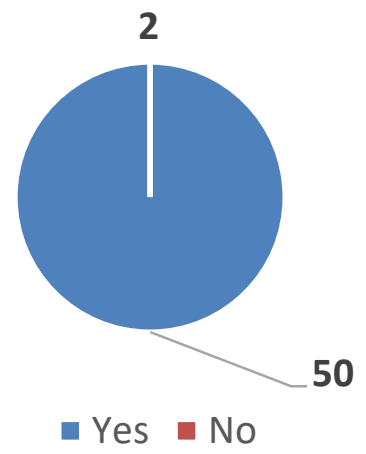

50 respondents agreed that training activities results in better co-ordination among work groups and 2 respondents did not agree to the statement.

9. Benefits of Training program

\begin{tabular}{|l|l|l|l|l|l|l|l|}
\hline & $\begin{array}{l}\text { Highly } \\
\text { Satisfie } \\
\mathrm{d}\end{array}$ & $\begin{array}{l}\text { Parti } \\
\text { ally } \\
\text { Satis } \\
\text { fied }\end{array}$ & Satisfied & Neutral & $\begin{array}{l}\text { Dissatisfi } \\
\text { ed }\end{array}$ & $\begin{array}{l}\text { Partially } \\
\text { Dissatisfi } \\
\text { ed }\end{array}$ & $\begin{array}{l}\text { Highly } \\
\text { Dissatis } \\
\text { fied }\end{array}$ \\
\hline $\begin{array}{l}\text { Improves } \\
\text { Performance }\end{array}$ & 23 & 10 & 14 & 4 & 0 & 0 & 1 \\
\hline $\begin{array}{l}\text { Enhance } \\
\text { organisational } \\
\text { effectiveness }\end{array}$ & 17 & 15 & 11 & 8 & 0 & 0 & 1 \\
\hline $\begin{array}{l}\text { Generate } \\
\text { innovative Ideas }\end{array}$ & 20 & 10 & 11 & 9 & 1 & 0 & 1 \\
\hline $\begin{array}{l}\text { Builds up team } \\
\text { work in }\end{array}$ & 21 & 12 & 11 & 6 & 1 & 0 & 1 \\
\hline $\begin{array}{l}\text { Results } \\
\text { adaptation of new } \\
\text { working methods }\end{array}$ & 10 & 12 & 8 & 0 & 0 & 1 \\
\hline
\end{tabular}




\section{Benefits of Training program}

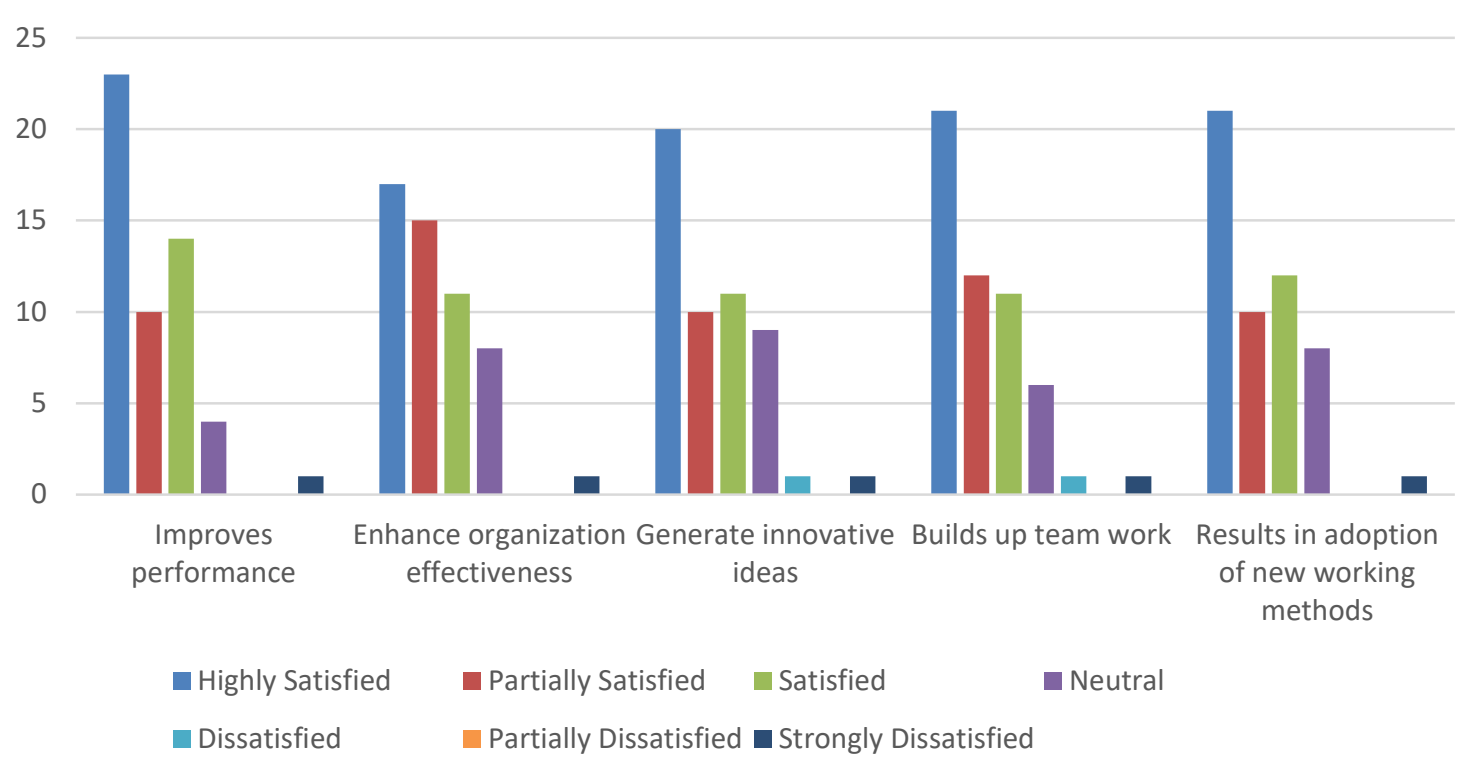

Majority of the respondents have mentioned that training programs are beneficial to the employees.

10. Flexibility in Working Hours

\begin{tabular}{|l|l|}
\hline Yes & 23 \\
\hline No & 9 \\
\hline Sometimes & 20 \\
\hline
\end{tabular}

Working hour flexibility

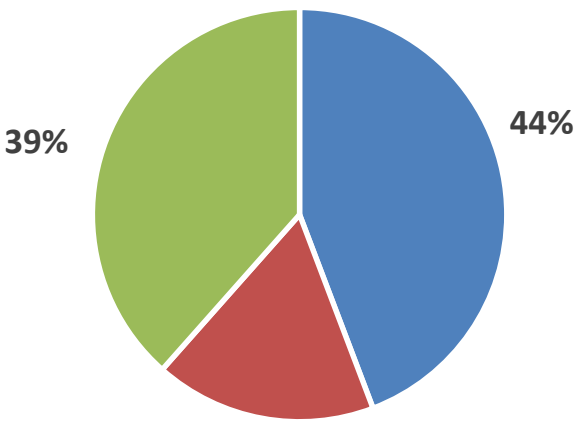

$17 \%$

- Yes - No - Sometimes

$44 \%$ of the employees prefer flexibility in working hours, $17 \%$ of the employees do not prefer flexibility in working hours and $39 \%$ of the employees sometimes prefer flexibility in working hours. 
11. If Yes, then when should the flexible working hours be applicable

\begin{tabular}{|l|l|}
\hline Weekdays & $85 \%$ \\
\hline Weekends & $9 \%$ \\
\hline Both & $6 \%$ \\
\hline
\end{tabular}

Yes, Then when are the flexible working hours be applicable

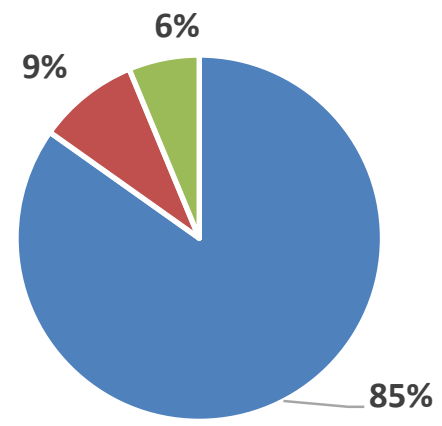

- Weekdays - Weekends - Both

$85 \%$ of employees prefer flexibility in working hours on weekdays, $6 \%$ of employees prefer flexibility in working hours on weekdays and on weekends and $9 \%$ of employees prefer flexibility in working hours on weekends.

12. Does flexi work policy results into better job satisfaction?

\begin{tabular}{|l|l|l|}
\hline Highly Satisfied & 12 \\
\hline Partially Satisfied & & 11 \\
\hline Satisfied & & 14 \\
\hline Neutral & 8 \\
\hline Dissatisfied & - \\
\hline Partially Dissatisfied & & - \\
\hline Strongly Dissatisfied & 1 \\
\hline
\end{tabular}

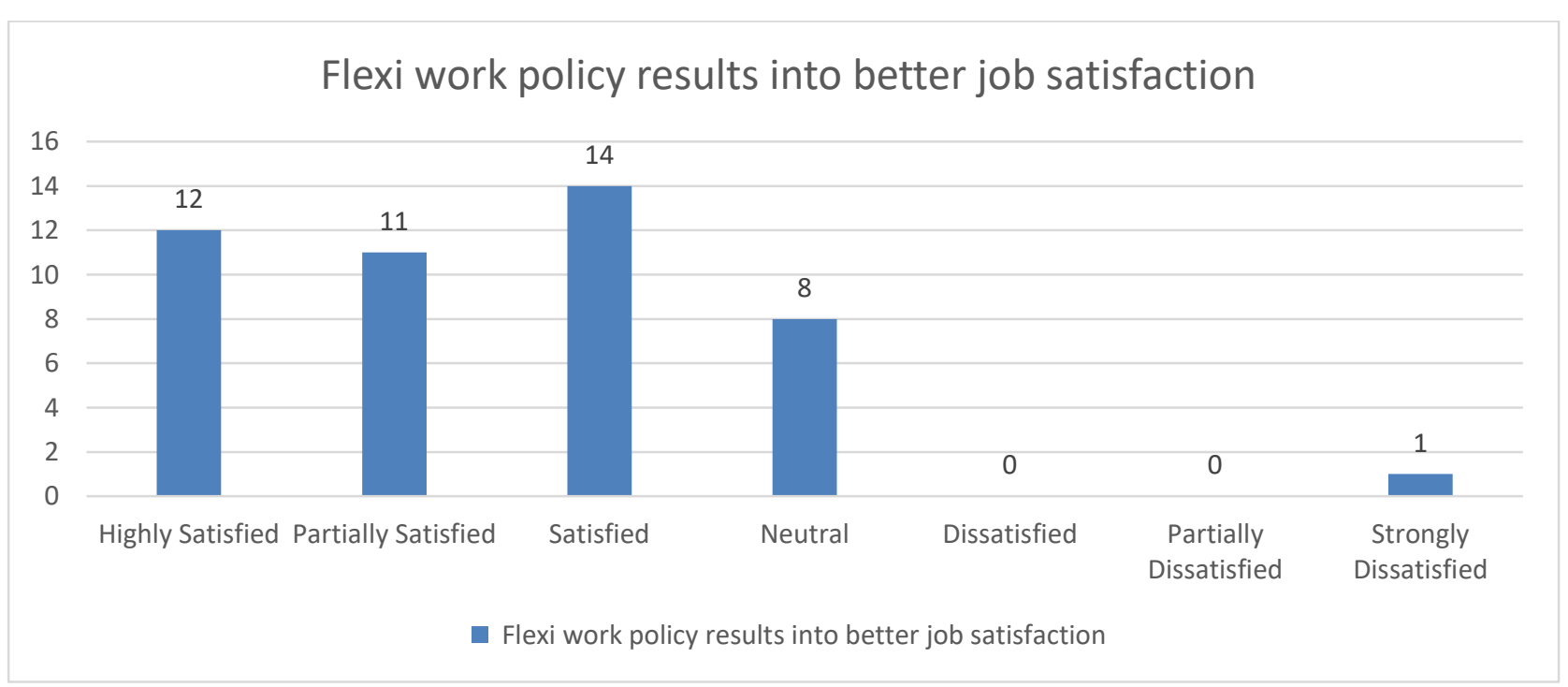


In the above logical data, they have defined about the flexibility of work policy for the employees, and also about how they are satisfied towards their work in the organisation. 12 respondents are highly satisfied where 11 are partially satisfied. 14 are only satisfied for the flexi policy results. 8 are neutral on this question and 1 respondent is strongly dissatisfied.

13. Introduction of flexi work policy has improved employees productivity and performance

\begin{tabular}{|l|l|}
\hline Yes & 47 \\
\hline No & 5 \\
\hline
\end{tabular}

Flexi work policy has improved productivity and performance

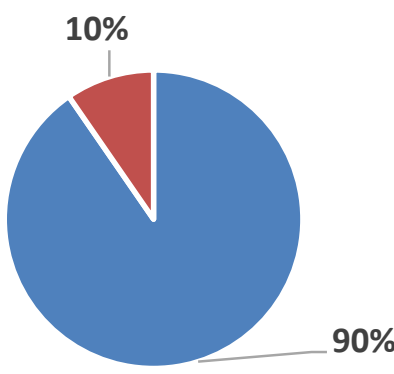

- Yes - No

There is an increasing concern on the quality of Jobs and productivity that is witnessed. In the flexible employment arrangements. However, the above study defines about the relationship between two employee arrangements and the workplace performance is been examined. It is the tool that use to enhance the job performance which are agreed by $90 \%$ and $10 \%$ disagreed.

14. Benefits of flexible working policy

\begin{tabular}{|l|l|l|l|l|l|l|l|}
\hline & $\begin{array}{l}\text { Strongly } \\
\text { Agree } \\
\text { Agree }\end{array}$ & $\begin{array}{l}\text { Partially } \\
\text { Agree }\end{array}$ & Neutral & Disagree & $\begin{array}{l}\text { Partially } \\
\text { Disagree }\end{array}$ & $\begin{array}{l}\text { Strongly } \\
\text { Disagree }\end{array}$ \\
\hline $\begin{array}{l}\text { Relieves } \\
\text { stress at } \\
\text { work }\end{array}$ & 15 & 12 & 18 & 3 & 0 & 0 & 1 \\
\hline $\begin{array}{l}\text { Gives Job } \\
\text { Satisfaction }\end{array}$ & 18 & 10 & 14 & 6 & 0 & 0 & 1 \\
\hline $\begin{array}{l}\text { Engagement } \\
\& \\
\text { Productivity }\end{array}$ & 14 & 14 & 12 & 6 & 2 & 0 & 1 \\
\hline $\begin{array}{l}\text { Employees } \\
\text { Morale }\end{array}$ & 17 & 9 & 12 & 7 & 3 & 0 & 1 \\
\hline $\begin{array}{l}\text { Strengthen } \\
\text { Team Work }\end{array}$ & 17 & 12 & 15 & 3 & 1 & 0 & 1 \\
\hline
\end{tabular}




\section{Scale of flexible working policy enhances}

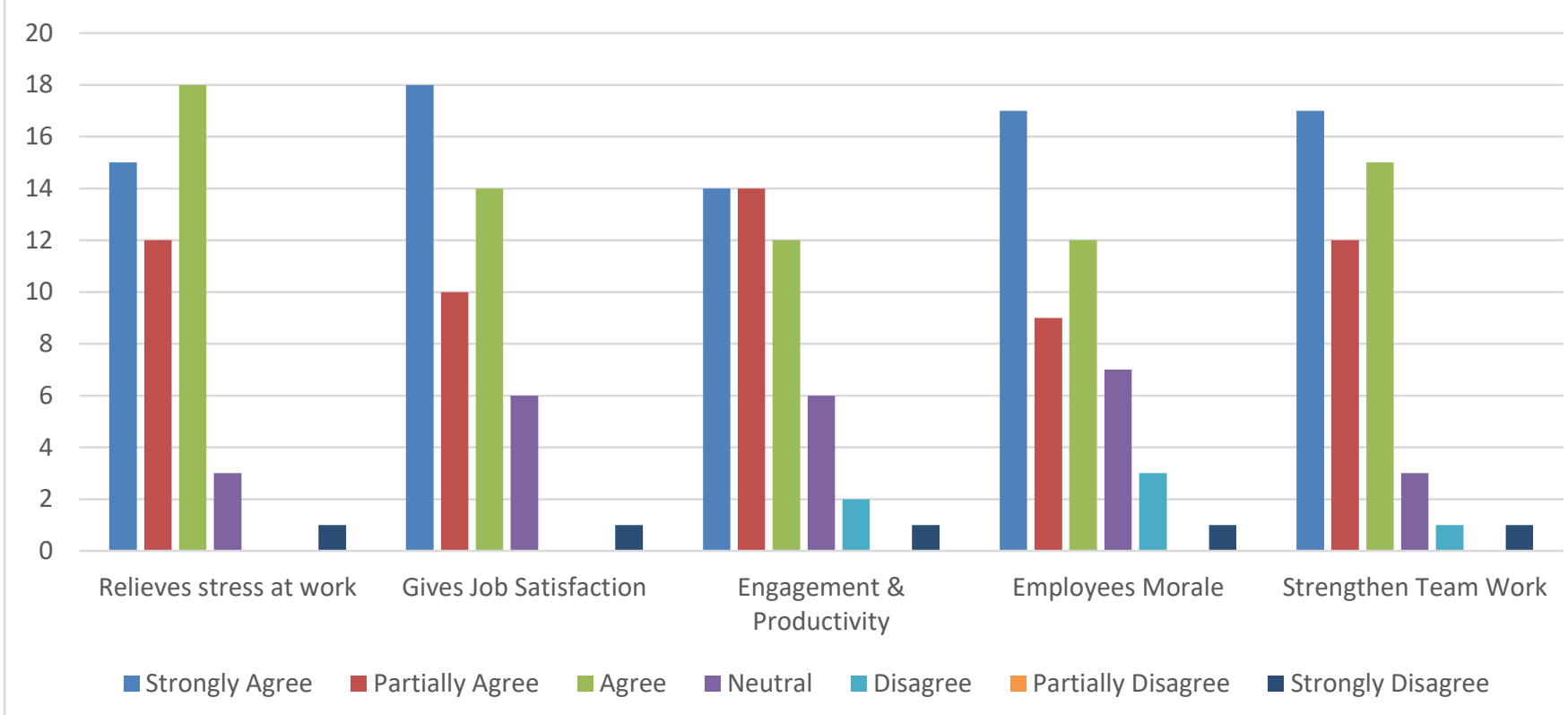

The above data and graph provides the detail of the flexible working policy provided and the above graph shows what are the employees about flexible working policy enhances. After analysing the above data and graph we come to know that the Relieves stress at work need graph is showing that most of the employees are satisfied by the flexible working policies. Only 1 person is strongly disagreed. Similarly, employees have mixed review regarding job satisfaction. Engagement \& productivity also have most strongly agree and partially agree. Employees' morale also have most strongly agree. Strengthen team work have most strongly agree After all we can conclude that Employees are satisfied by Flexible working process.

15. Organisation encourage cross functional job rotation.

\begin{tabular}{|l|l|}
\hline Yes & 33 \\
\hline No & 19 \\
\hline
\end{tabular}

\section{Organisation encourage cross functional job rotation}

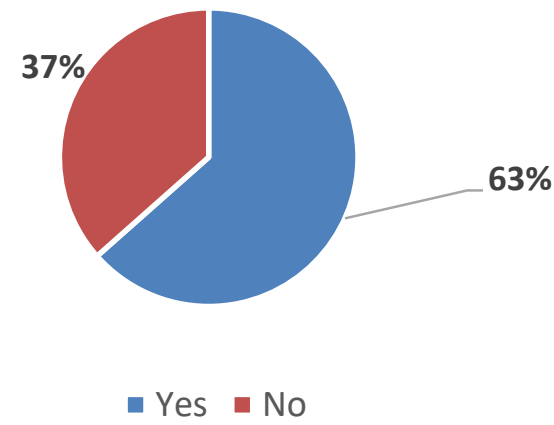

Job Rotation involves an employee changing positions within the same organization and eventually returning to the original position. The employees agreed percentile are $63 \%$ and 
disagreed to $37 \%$. It can refer to various types of rotation to encourage and employees get highly motivated as they can work accordingly as per their demands.

16. If yes, how frequently does rotation takes place.

\begin{tabular}{|l|l|}
\hline Quarterly & 10 \\
\hline Six month & 23 \\
\hline Yearly & 1 \\
\hline
\end{tabular}

If yes, how frequently does rotation takes place

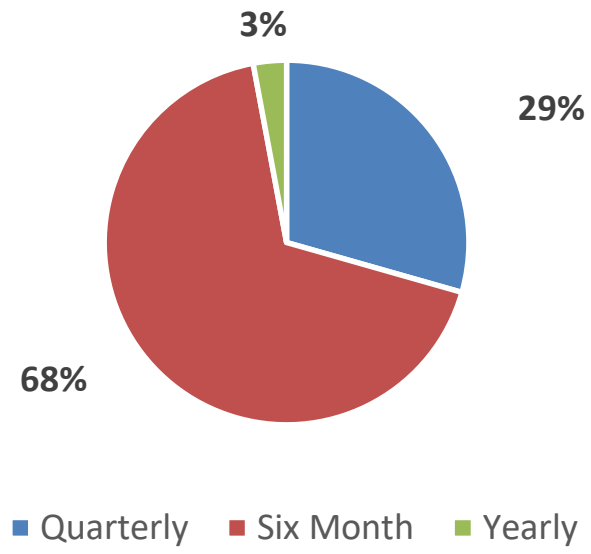

Job rotation is the systematic movement of employees from one job to another within the organization to achieve various human resources objectives such as orienting new employees, training employees, enhancing career development and preventing job boredom and burnout. The responses for Rotation period within six months is 68\%, Quarterly 29\% and Yearly 3\%. Cross Functional rotation is usually concerning the position with the increasing level and responsibilities of the job or a promotion.

17. Reasons for carrying out a cross functional job rotation.

\begin{tabular}{|l|l|}
\hline To encourage development of employees & 21 \\
\hline $\begin{array}{l}\text { Gives employees a break from strenuous job } \\
\text { duties }\end{array}$ & 3 \\
\hline $\begin{array}{l}\text { Helps employee to identify where they work } \\
\text { best }\end{array}$ & 8 \\
\hline To build an informed work force & 3 \\
\hline Fresh perspectives on existing roles & 2 \\
\hline Any Other & 2 \\
\hline
\end{tabular}




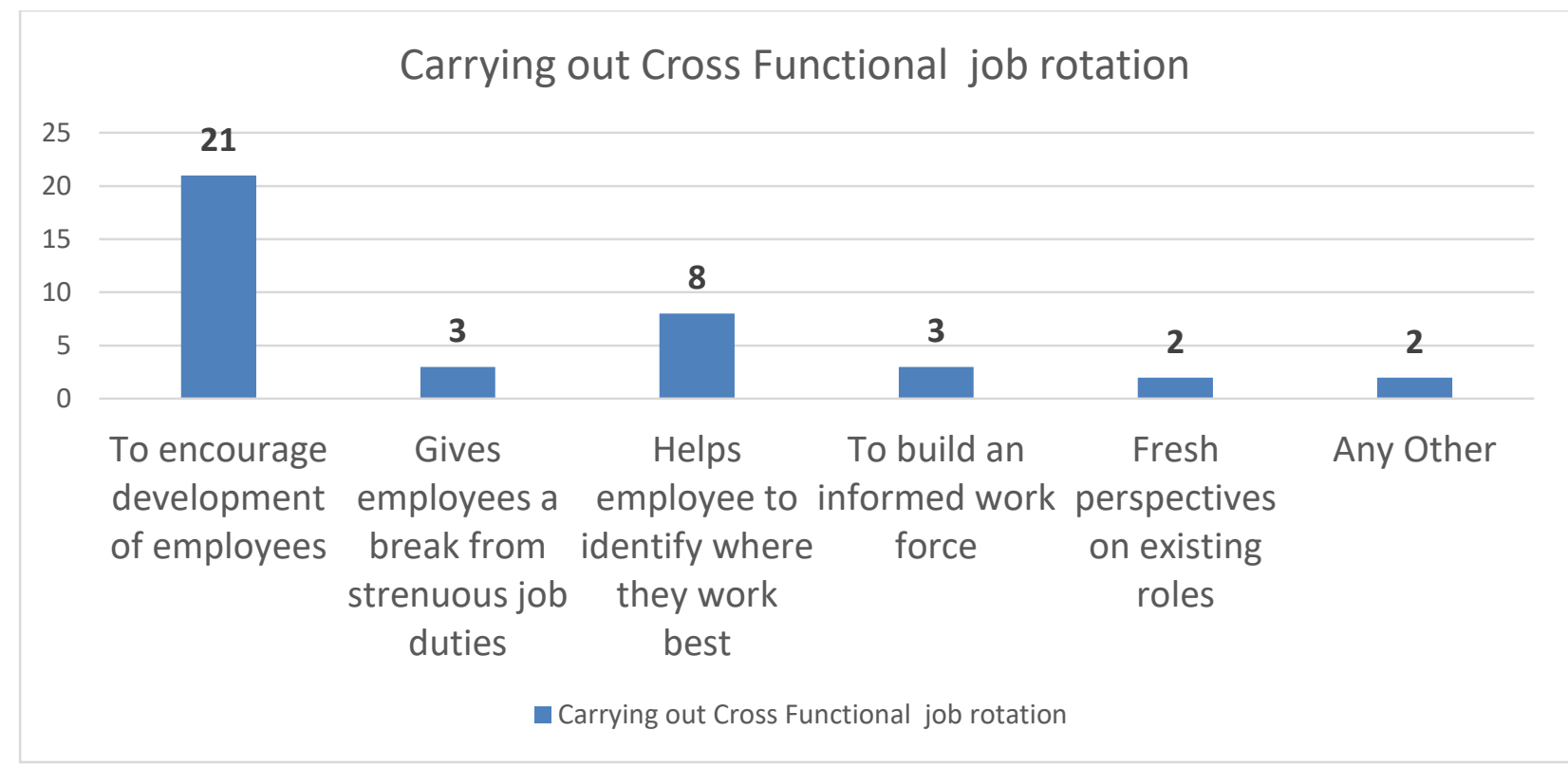

21 of respondents saying that their organisation provides cross functional job rotation to encourage development of employees. 8 are saying cross functional job rotation helps employees to identify where they work best. 3 says it gives employees break form strenuous job duties. 2 are saying it helps to get fresh perspective on existing roles.

18. Job rotation helps to develop Knowledge, Skills and change in the Attitude of the employees

\begin{tabular}{|l|l|}
\hline Strongly Agree & 16 \\
\hline Partially Agree & 7 \\
\hline Agree & 23 \\
\hline Neutral & 6 \\
\hline Disagree & - \\
\hline Partially Disagree & - \\
\hline Strongly Disagree & - \\
\hline
\end{tabular}

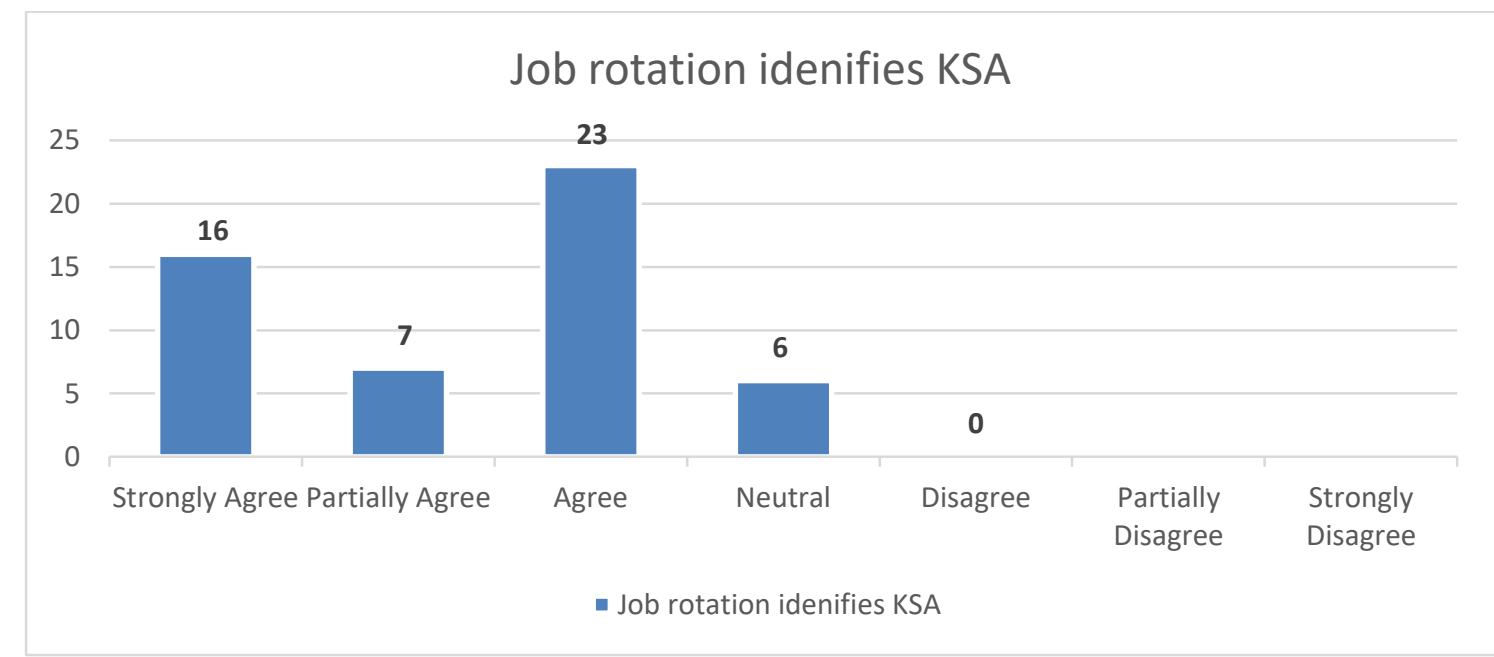

Here we asked whether job rotation helps them to improve their KSA i.e knowledge, skills and attitudes. 16 respondents responded as they are strongly agree for the KSA. 7 are saying they are partially agree. 23 responded as agree and 6 neutral. 
19. Factors responsible for retention of employees due to job rotation.

\begin{tabular}{|l|l|}
\hline Accelerates professional development & 27 \\
\hline $\begin{array}{l}\text { Helps employee to identify where they } \\
\text { work best }\end{array}$ & 28 \\
\hline Better co-ordination between subordinates & 26 \\
\hline $\begin{array}{l}\text { Encourage employees to be a part of } \\
\text { succession plan }\end{array}$ & 19 \\
\hline $\begin{array}{l}\text { Gives employees a break from strenuous } \\
\text { job duties }\end{array}$ & 12 \\
\hline $\begin{array}{l}\text { Reduce attrition as there is always } \\
\text { something new to learn/work }\end{array}$ & 12 \\
\hline Improved work life balance & 11 \\
\hline Help improve team building with managers & 12 \\
\hline Learning of new skills / additional training & 21 \\
\hline
\end{tabular}

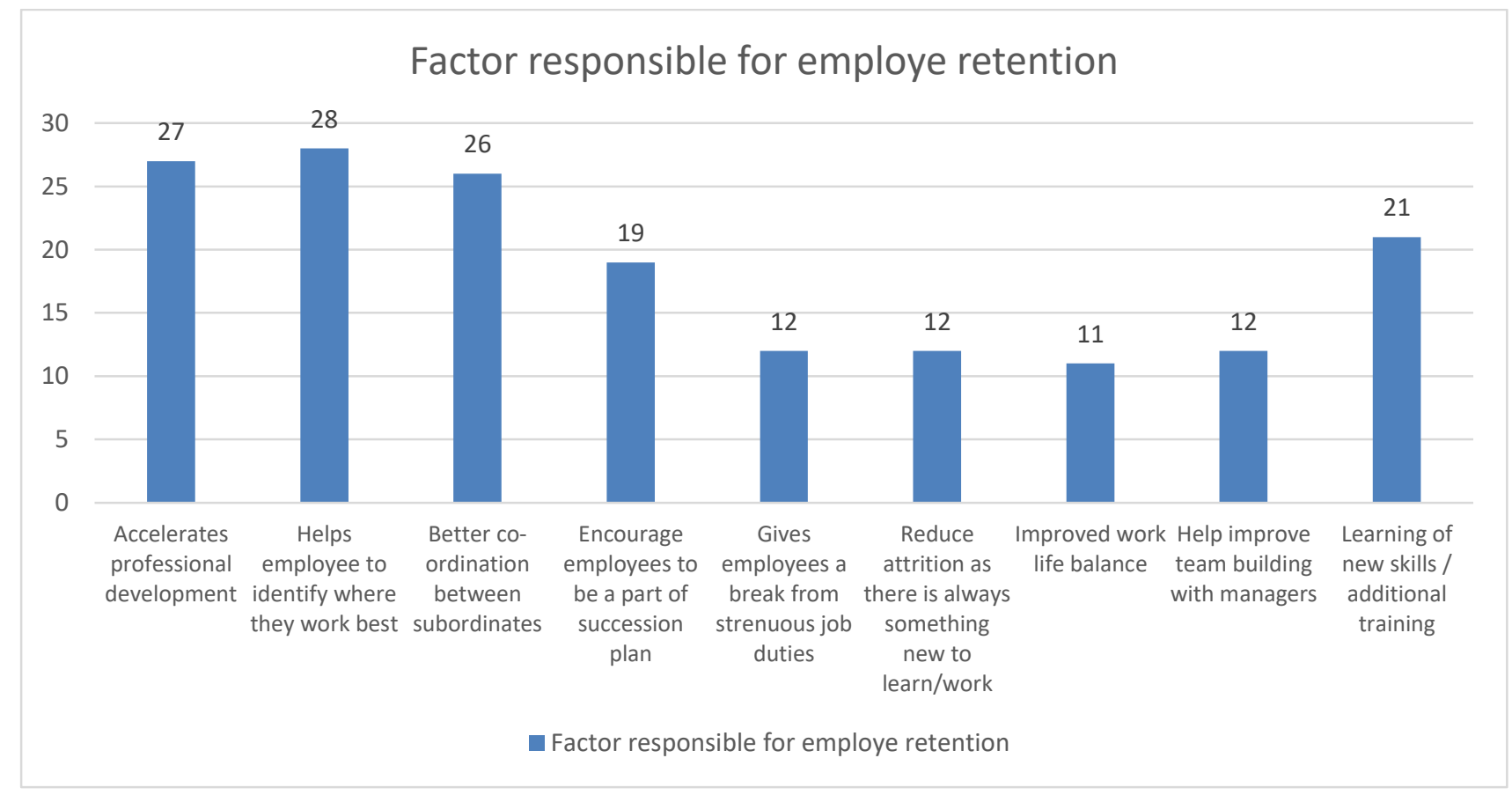

Above are the factors responsible for employee retention where 27 respondents say that acceleration of professional development is factor responsible for retention. 28 says helps to identify where they work best. 26 responses as better co-ordination between subordinate can be factor for employee retention.19 are saying encouraging can be part of succession plan for employee retention.

20. Encouragement given to the employees for pursuing higher education

\begin{tabular}{|l|l|}
\hline Yes & 38 \\
\hline No & 12 \\
\hline
\end{tabular}




\section{Organisation encourage higher education}

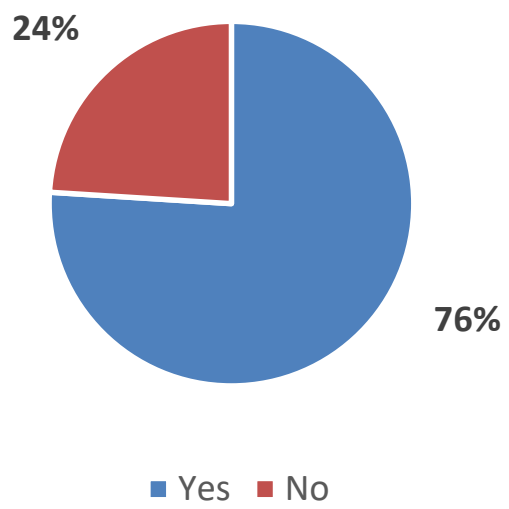

$76 \%$ of the respondents are responded Yes as organization encourage higher education. So we can say that organization may allow their employees to take more knowledge and improve the quality of work. $24 \%$ responded as their organization don't encourage to take higher education.

21. Organisation provides sabbatical leaves for pursuing higher education.

\begin{tabular}{|l|l|}
\hline Yes & 32 \\
\hline No & 20 \\
\hline
\end{tabular}

Organisation provides sabbatical leaves

$38 \%$

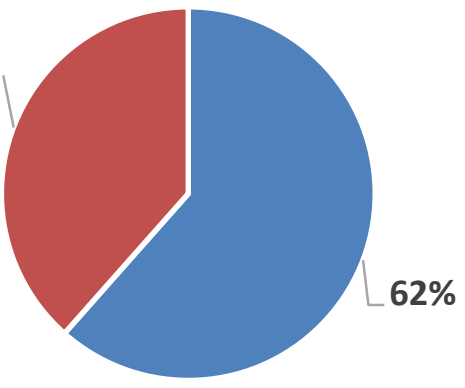

- Yes - No

$62 \%$ of the respondents says their organisation provides sabbatical leaves. Where $38 \%$ responded as their organisation don't provide any sabbatical leaves.

22. Organization grant leave for exams while employees are pursuing higher education/ additional course.

\begin{tabular}{|l|l|}
\hline Yes & 37 \\
\hline No & 15 \\
\hline
\end{tabular}




\section{Organization grant leave for exams while you are pursuing higher education}

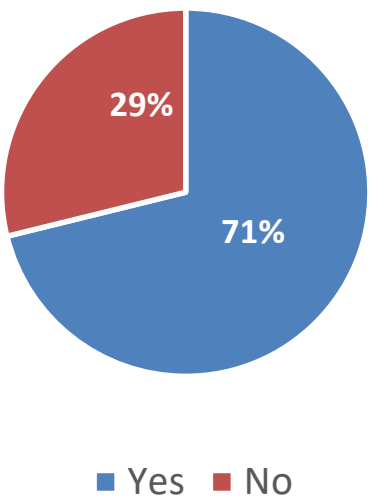

37 respondents comes to $71 \%$ says their organisation grants leave for exams while pursuing higher education. $29 \%$ respondents as 15 respondents says their organisation don't provide grant leave for exams while pursuing higher education.

23. If yes, for how many days leave is granted.

\begin{tabular}{|l|l|}
\hline One Week & 16 \\
\hline Fortnightly & 6 \\
\hline One Month & 9 \\
\hline
\end{tabular}

If Yes, How many days

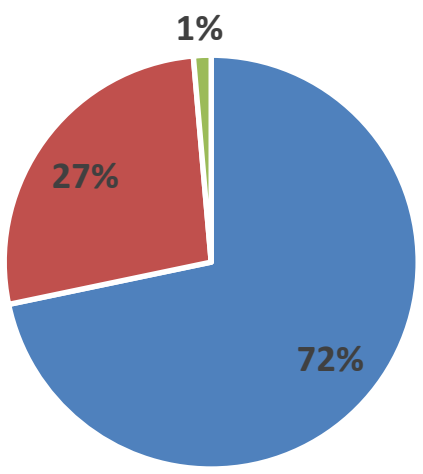

- One week - Fortnightly - One month

As we saw in earlier, 37 respondents said their organisation grant leave for pursuing higher education. From these respondents $72 \%$ said they have one week leave, $27 \%$ replied as organisation grant leave for fortnight and $1 \%$ replied as they get one month leave for pursuing higher studies. 
24. Factors influence employees to remain in the organization?

\begin{tabular}{|l|l|}
\hline Salary & 34 \\
\hline Flexi-work hours & 13 \\
\hline Health and wellness benefits & 13 \\
\hline Recognition and rewards & 37 \\
\hline $\begin{array}{l}\text { Training and development / Learning and } \\
\text { development activities }\end{array}$ & 28 \\
\hline Job security & 18 \\
\hline Career growth opportunities & 30 \\
\hline Retirement benefits & 7 \\
\hline Any other & 5 \\
\hline
\end{tabular}

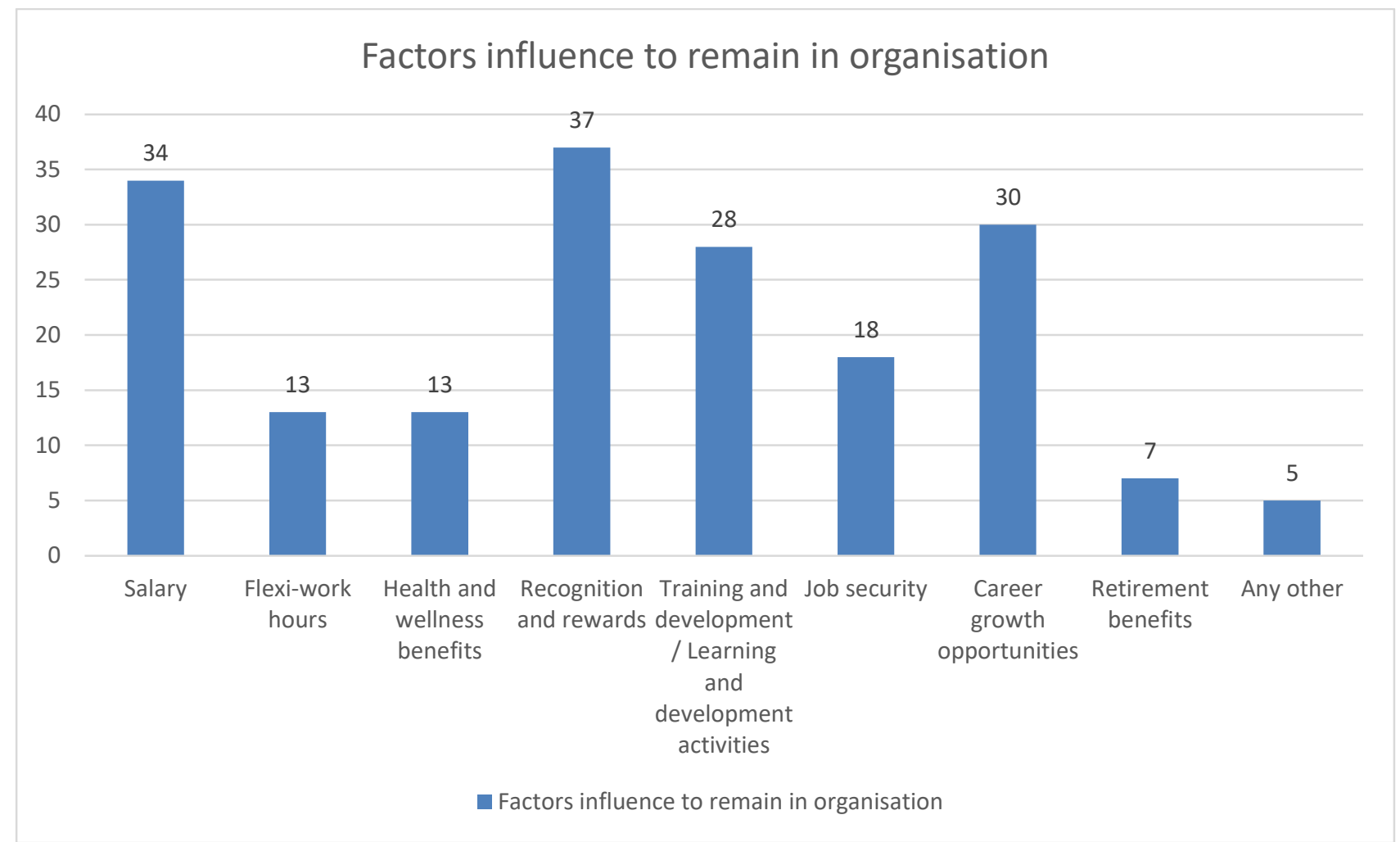

Above are the factors which influences the employee to retain in organisation. 34 respondents says salary is one of the important factor, 13 says flexi-work hours may be a factor to remain in organisation. 13 respondents says health and wellness benefits can be a factor, 37 respondents says recognition and rewards can be a main factor to retain in organisation. This is the most important factor which most of the respondents have responded. 28 respondents are saying training and development activities may influence, 18 saying job security can be the important factor to retain in organisation.30 responses are in career growth opportunity, 7 are saying retirement benefits and 5 have other factors which influences for retention in organisation. 
25. Employee Retention strategies

\begin{tabular}{|l|l|l|l|l|l|}
\hline & 1 & 2 & 3 & 4 & 5 \\
\hline $\begin{array}{l}\text { Working } \\
\text { Environment }\end{array}$ & 3 & 2 & 14 & 17 & 16 \\
\hline $\begin{array}{l}\text { Work done is } \\
\text { appreciated }\end{array}$ & 2 & 7 & 10 & 18 & 15 \\
\hline Insurance schemes based & 11 & 6 & 10 & 18 & 7 \\
\hline $\begin{array}{l}\text { Performance ancentives } \\
\text { ind }\end{array}$ & 5 & 3 & 15 & 22 & 10 \\
\hline $\begin{array}{l}\text { Compensation } \\
\text { Benefit }\end{array}$ & 3 & 9 & 22 & 13 \\
\hline
\end{tabular}

\section{Retention Strategy Scale}

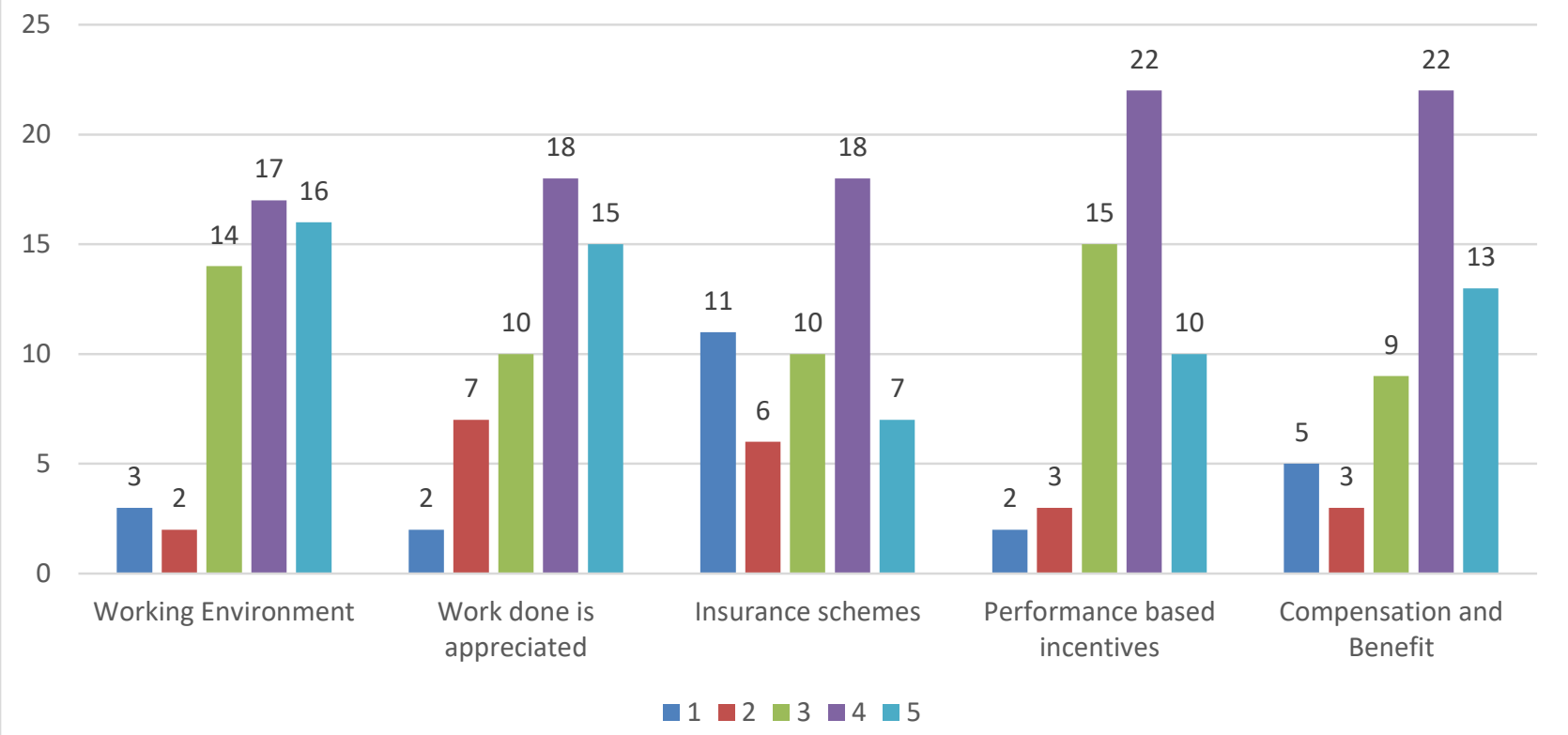

5 point scale of retention strategy is responded by respondents. In working experience 17 responded on $4^{\text {th }}$ point which is the highest among other rating scale. 18 have responded highest in work done is appreciated. 18 responded highest at $4^{\text {th }}$ scale on insurance scheme. 22 respondents have given $4^{\text {th }}$ scale rating which is highest for performance based incentives retention strategy. In retention strategy compensation and benefit 22 respondents gave $4^{\text {th }}$ scale which is highest for the same.

\section{Suggestions}

- Giving grant for higher studies may help the employees to upgrade their skills and have better understanding of current market trends.

- Sabbatical leaves for higher studies also help the employees for career growth opportunity and helps the organisation to create good image in minds of employees.

- Main point to be noted is that job security, salary is the most important factors to retain the employees. 
- Performance based incentives can also be adopted by the organisations for retaining its employees.

\section{Conclusion}

The organisations should provide continuous training and development programmes. In addition to this cross functional job rotation and providing flexi work policy leads to improve the productivity of employees.

\section{Bibliography:}

https://www.hrtechnologist.com/articles/employee-engagement/what-is-employee-retentiondefinition-strategy-examples/

https://www.managementstudyguide.com/employee-retention.htm https://en.wikipedia.org/wiki/Employee_retention https://www.hr360.com/Human-Resources/Employee-Retention.aspx https://apparelresources.com/business-news/manufacturing/stitchworld-project-employeeengagement-apparel-industry/ https://www.aspirehiring.ca/the-importance-of-employee-retention/ https://smallbusiness.chron.com/employee-retention-strategies-important-1241.html https://www.insala.com/blog/why-employee-retention-is-important https://www.tellermate.com/news-and-resources/employee-retention-retail-important-ever/ https://harver.com/blog/reasons-for-employee-turnover-in-retail/ https://medium.com/orquest/how-to-reduce-employee-turnover-at-the-retail-industrycf16ca4df4b5

https://www.indiaretailing.com/2016/05/13/retail/9-smart-tips-for-retaining-talent-in-theretail-industry/

http://article.sapub.org/10.5923.j.hrmr.20180803.03.html https://www.ibef.org/industry/indian-textiles-and-attire-industry-analysis-presentation https://www.ibef.org/industry/retail-india.aspx https://www.ibef.org/industry/indian-retail-industry-analysis-presentation https://www.mordorintelligence.com/industry-reports/retail-industry https://www.scribd.com/document/287660323/Textile-Reutyutyport-2015-1 https://www.valueline.com/Stocks/Industries/Industry_Overview_Attire.aspx

https://earmarkongaille.com/20-retail-attire-industry-statistics-trends-analysis/ https://www.sciencedirect.com/topics/engineering/textile-and-attire-industry http://www.ftms.edu.my/journals/index.php/journals/ijabm www.jbrmr.com www.bbronline.com.br http://www.iim.ftn.uns.ac.rs/ijiem_journal.php https://www.researchgate.net/profile/Idris_Aida/publication/302958708_Flexible_Working_a s_an_Employee_Retention_Strategy_in_Developing_Countries_Malaysian_Bank_Managers _Speak/links/573446b008ae9ace840748b9/Flexible-Working-as-an-Employee-RetentionStrategy-in-Developing-Countries-Malaysian-Bank-Managers-Speak.pdf\#page $=3$ 


\section{Annexure:}

\section{QUESTIONNAIRE}

Analytical Study on the effectiveness of strategies adopted for Employee Retention in Organized Apparel Retail Sector

Please provide following information for my research. I assure that all the information is strictly for academic purpose and will be kept confidential.

The employees will consist of people working in various functions in apparel retail sector with an experience of minimum three years and having maximum educational qualification as graduation and minimum educational qualification as $12^{\text {th }} \mathrm{std}$.

Date:

Name of the organization:

Name of the Mall:

Location / Branch:

Name of the respondent:

Gender:

Age:

Designation :

Contact No. :

E-mail :

Educational qualification:

Total experience in apparel retail sector ( years ):

Experience in current organization ( years ):

1. Since how many years you are working in the organization?

○ 3-5 years

○ 6-10 years

○ 11-15 years

- More than 15

2. Does your organization carry out training and development activities?

- Yes

○ No

3. What are the current training and development activities carried out by your organization?

○ Management Development

○ Soft skills Development

- Technical Skills Development (Department wise training)

- Personal Effectiveness

- Basic Skill Development

- Time Management

○ Effective Leadership 
4. What type of On the job training program does the organization offers?

○ Coaching

○ Mentoring

○ Job Rotation

5. What type of Off the job training program does the organization offers?

- Lectures And Conferences

- Simulation Exercises

- Sensitivity Training

6. Do you feel that these training activities help you in your career growth opportunities?

○ Strongly Agree

○ Partially Agree

○ Agree

- Neutral

- Disagree

○ Partially Disagree

- Strongly Disagree

7. Have you experienced that post training program results in better work efficiency?

- Yes

○ No

8. Do these training activities have resulted in better co-ordination among work groups?

○ Yes

○ No

9. Rate the following based on your opinion.

- Do you think Training program?

\begin{tabular}{|l|l|l|l|l|l|l|l|l|}
\hline & $\begin{array}{l}\text { Highly } \\
\text { Satisfied } \\
\text { 1. }\end{array}$ & $\begin{array}{l}\text { Partiall } \\
\text { Satisfie } \\
\mathrm{d}\end{array}$ & $\begin{array}{l}\text { Satisfie } \\
\mathrm{d}\end{array}$ & Neutral & $\begin{array}{l}\text { Dissatisfie } \\
\mathrm{d}\end{array}$ & $\begin{array}{l}\text { Partially } \\
\text { Dissatisfie } \\
\mathrm{d}\end{array}$ & $\begin{array}{l}\text { Highly } \\
\text { Dissatisfie } \\
\mathrm{d}\end{array}$ \\
\hline 2. & $\begin{array}{l}\text { Enhance } \\
\text { organization } \\
\text { effectivenes } \\
\text { s }\end{array}$ & & & & & & & \\
\hline 3. & $\begin{array}{l}\text { Generate } \\
\text { innovative } \\
\text { ideas }\end{array}$ & & & & & & & \\
\hline
\end{tabular}




\begin{tabular}{|l|l|l|l|l|l|l|l|}
\hline 4. & $\begin{array}{l}\text { Builds up } \\
\text { team work }\end{array}$ & & & & & & \\
\hline 5. & $\begin{array}{l}\text { Results in } \\
\text { adoption of } \\
\text { new working } \\
\text { methods }\end{array}$ & & & & & & \\
\hline
\end{tabular}

10. Does your organization provide flexibility in working hours?

○ Yes

○ No

○ Sometimes

11. If yes, then when are they applicable?

○ Weekdays

- Weekends

○ Both

12. Does flexi work policy results into better job satisfaction?

- Highly Satisfied

- Partially Satisfied

- Satisfied

- Neutral

○ Dissatisfied

- Partially Dissatisfied

○ Strongly Dissatisfied

13. Does introduction of this flexi work policy improved your productivity and performance?
○ Yes
○ No

14. Rate the following

- Flexible working policy Enhance?

\begin{tabular}{|l|l|l|l|l|l|l|l|l|}
\hline & & $\begin{array}{l}\text { Strongly } \\
\text { Agree }\end{array}$ & $\begin{array}{l}\text { Partially } \\
\text { Agree }\end{array}$ & Agree & Neutral & Disagree & $\begin{array}{l}\text { Partially } \\
\text { Disagree }\end{array}$ & $\begin{array}{l}\text { Strongly } \\
\text { Disagree }\end{array}$ \\
\hline 1. & $\begin{array}{l}\text { Relieves stress at } \\
\text { work }\end{array}$ & & & & & & & \\
\hline 2. & $\begin{array}{l}\text { Gives Job } \\
\text { satisfaction }\end{array}$ & & & & & & & \\
\hline
\end{tabular}




\begin{tabular}{|l|l|l|l|l|l|l|l|l|}
\hline 3. & $\begin{array}{l}\text { Engagement \& } \\
\text { productivity }\end{array}$ & & & & & & & \\
\hline 4. & $\begin{array}{l}\text { Employees } \\
\text { morale }\end{array}$ & & & & & & & \\
\hline 5. & $\begin{array}{l}\text { Strengthen team } \\
\text { work }\end{array}$ & & & & & & & \\
\hline
\end{tabular}

15. Do your organization encourage cross functional job rotation?

○ Yes

○ No

16. If yes, then how frequently does rotation takes place?

○ Quarterly

○ Six Months

○ Yearly

17. Which of the following reasons are most important for carrying out a cross functional job rotation?

- To encourage's development of employees

- Gives employees a break from strenuous job duties

- Helps employee to identify where they work best

- To build an informed work force

- Fresh perspectives on existing roles

○ Any other

18. Do you think job rotation identify KSA - Knowledge, Skills, Attitudes?

- Strongly Agree

- Partially Agree

- Agree

○ Neutral

- Disagree

○ Partially Disagree

○ Strongly Disagree

19. What could be the factors responsible for retention of employee due to job rotation?

- Accelerates professional development

- Helps employee to identify where they work best

- Better co-ordination between subordinates 
- Encourage employees to be a part of succession plan

- Gives employees a break from strenuous job duties

○ Reduce attrition as there is always something new to learn/work

- Improved work life balance

- Help improve team building with managers

$\circ$ Learning of new skills / additional training

20. Does your organisation encourage you to take higher education?

○ Yes

○ No

21. Does your organisation provide you with sabbatical leave for pursing higher education /additional course?

○ Yes

○ No

22. Does your organization grant leave for exams while you are pursuing higher education/ additional course?

- Yes

○ No

23. If yes, then how many days leave is granted?

o One week

○ Fortnightly

○ One month

24. Which of the following factors influence you to remain in the organization?

○ Salary

- Flexi-work hours

- Health and wellness benefits

- Recognition and rewards

- Training and development / Learning and development activities

- Job security

- Career growth opportunities

- Retirement benefits

- Any other 
25. Please rate the following employee retention strategies on the scale of statements on 1 to 5 (1lowest, 5- highest)

\begin{tabular}{|l|l|l|l|l|l|l|}
\hline $\begin{array}{l}\text { SR. } \\
\text { No. }\end{array}$ & Provisions & 1 (low) & 2 & 3 & 4 & $5($ High) \\
\hline 1. & Working environment & & & & & \\
\hline 2. & Work done is appreciated & & & & & \\
\hline 3. & Insurance schemes & & & & & \\
\hline 4. & Performance based incentives & & & & & \\
\hline 5. & Compensation and benefit & & & & & \\
\hline
\end{tabular}

26. Please specify any other strategies that result in employee retention? 